\title{
Exploring the Entrepreneurial Environment for Agricultural Processors and developing Strategy to promote Value Addition via Alfares' Method
}

\author{
Shruti $^{1 *}$, M. Singh ${ }^{2}$ and J.P. Sharma ${ }^{3}$ \\ ${ }^{1}$ ICAR-Directorate of Mushroom Research, Solan-173213, HP, India \\ ${ }^{2}$ ICAR-Indian Institute of Soil and Water Conservation, Dehradun-248195, UK, India \\ ${ }^{3}$ ICAR-Indian Agricultural Research Institute, New Delhi-110012, India
}

*Corresponding author

\section{A B S T R A C T}

\begin{tabular}{|c|}
\hline Keywords \\
\hline $\begin{array}{l}\text { Entrepreneurial } \\
\text { environment, } \\
\text { processing unit, } \\
\text { Strategy, Alfares } \\
\text { method, Driving } \\
\text { and restraining } \\
\text { forces }\end{array}$ \\
\hline Article Info \\
\hline $\begin{array}{l}\text { Accepted: } \\
15 \text { November } 2018 \\
\text { Available Online: } \\
10 \text { December } 2018\end{array}$ \\
\hline
\end{tabular}

The study was carried out to identify the entrepreneurial environment for different processors like fruit (aonla, guava and mango), vegetable (tomato, potato and mushroom) and foodgrain (maize, wheat and soybean). The 15 processors from each commodity were randomly selected from purposively selected districts. It was found that the entrepreneurial environment was most promoting to soybean processor (614.71) followed by aonla processor (567.00). The driving force of soybean processor was highest for technical (119.4), infrastructure (118.33) and legal (117.23) dimensions however, for aonla processor, the financial 102.36) and socio-personal (101.43) dimensions were highest. The entrepreneurial environment was lowest for potato processor (135.51) due to least driving forces. In case of restraining forces, guava processor (546.35) ranked first and wheat processor (270.37) ranked lowest. It was found that the net return was more in processing unit compared to production unit in all the selected commodities. Thus, processing lead to realized more income and increased shelf life of produce. Therefore, strategy was devise to promote value addition among producer through experts' opinion and using Alfares method. It was found that the effective information transfer (94.62) and institutional support (86.86) followed by linkage of processed products with market (83.28) can be beneficial.

\section{Introduction}

The success of enterprises is a function of both external and internal factors (Penrose, 1959; McCline et al., 2000; Guzman and Santos, 2001; Markman and Baron, 2003). External factors have been found to have an impact on the performance potential of firms. Organizational ecology, introduced by Hannan and Freeman (1977), suggests that organizations are constrained by the external environment they operate in and, consequently, the firm's growth is determined largely by these external forces. Dahlqvist $e t$ al., (2000) pointed out that external factors present opportunities, threats and information with the potential to affect all entrepreneurs within their environment, regardless of their 
background, education or business concept. Guzman and Santos (2001) listed external factors to include socio-demographics, markets (local, international, emerging and established markets), cultural, economic, political, institutional, legal, productive, technological, infrastructure and other physical factors of that particular environment.

Researchers investigated the antecedents of entrepreneurial success and included economic, psychological, sociological, and management factors. Economic factors include the effective use of planning and strategies, entrepreneurial orientation, innovativeness and tough environmental environment (Rauch and Frese, 2000). Psychological factors include the entrepreneurial behaviours like moderate risk taking, achievement motivation, locus of control, problem-solving orientation, creativity, proactive, self-efficacy ( $\mathrm{Nel}$ et al., 2008) positive attitude and persistence (Caliendo and Kritikos, 2008; McClelland, 1961). Social factors include the strength of social networks and the social skills of the entrepreneur (Brush, 2008; Walske et al., 2007). Management factors include minimum cost, output, visioning and bootstrapping (Brush, 2008) as well as entrepreneur's qualifications, aim pursued, and the training scheme utilized (Bonet et al., 2011). Several investigators had different opinion regarding the factors which determine the success or failure of enterprise.

Few of the authors suggested that there are various indicators which determine the success of entrepreneurs. These indicators explain, predict and ascertain the enterprise success. Black et al., (2010) explored the possible traits, skills and abilities present in individuals to predict the entrepreneurial behaviour. However, Kumar (2007) uses psycho-social process to develop conceptual framework that explain entrepreneurial success. Identifying indicators of entrepreneurial success is problematic because it has many diverse dimensions and is a multistage process (Brockner et al., 2004). Furthermore, each indicator of entrepreneurial success is a multidimensional phenomenon in its own right, as exemplified by the work on the heterogeneity of growth indices (Delmar $e t$ al., 2003).

Numerous authors highlighted economic, financial and legal aspects as significant for growth of enterprise in developed as well as developing countries. Thompson (2001) pointed out that the economic conditions affect how easy or how difficult it is to be successful and profitable at any time because they affect both capital availability and cost, and demand. Data from several sources have identified financial resources as a fundamental element for the success of businesses. Indeed, entrepreneurs need to have sufficient financial resources in order not only to help their businesses during the start-up phase but also throughout the lifetime of the business. Beck et al., (2006) argued that in a competitive business environment, availability of financial resources is cardinal for the development process as it facilitates entry, exit and growth of firms. Robertson et al., (2003) pointed out that one of the key factors inhibiting SME development is taxation. If tax rates are high, they reduce the profit incentive drastically (Ahwireng-Obeng and Piaray, 1999).

Thus, we can infer that entrepreneurial success is a phenomenon that likely to be decided by implication or context. In both the way subjectively and objectively the success of enterprise can be determined. However, the entrepreneurial environment varies from person to person and region to region and similarly the parameters for achievement differs across the dimensions. The present study considered the following dimensions of entrepreneurial environment as determinant of enterprise success i.e. technical, infrastructure, market, finance, legal and socio-personal 
dimensions. These dimensions were seen in both the way whether it is driving or restraining the enterprise growth.

In case of driving forces, the technical dimension considered the availability of raw material, its suitable variety for processing, skilled labour, access to technical information etc. Infrastructure dimension considered the institutional support, logistic facility, grading and packaging facility. However, the market dimension included access to direct marketing and purchasing of raw material, online marketing and access to market information whereas, financial dimensions considered banking facility, ease in loan, insurance and favourable price policy. The legal dimension considered the ease in registering unit, quality and safety standards, implication of GST and digital payment however, the socio-personal dimension considered innovativeness, risk taking ability, family support and internal locus of control.

In case of restraining forces, the technical dimension considered training and its follow up, enterprise diversification support, cost of machines etc. Further, for infrastructure dimension, high initial investments, storage facility, nearby machinery available, interrupted power supply etc. were included whereas the market dimension considered price fluctuation of raw material, middleman existence, difficulty in predicting demand and price, distress sale and problem in negotiating contracts.

The finance dimension considered difficulty in obtaining subsidy, long payback period, and high interest rate while the legal dimensions included difficulty in obtaining licence, effect of demonetization and GST on enterprise. The socio-personal dimension considered lacking entrepreneurial education, difference based on caste, motivation and negative attitude towards society.
Thus, the entrepreneurial environment plays a significant role in the success of enterprise. In this study the enterprise is referred to food processing unit like fruits, vegetable and foodgrain processing unit. The study identified the various dimensions of entrepreneurial environment which affects the different processing units, compared the profitability between processing unit and production unit then finally devised the strategy to promote value addition among producer.

\section{Materials and Methods}

\section{Sampling}

The nine agricultural commodities like food grains (Maize, Wheat and Soybean); vegetables (Potato, Tomato and Mushroom) and fruits (Mango, Guava and Aonla) were selected purposively based on their postharvest losses and/or potential for undergoing value addition as indicated in Table 1.

After the selection of agricultural commodities, the states and further districts were selected purposively for each identified agricultural commodities based on high production under crop and/or potential for value addition. Selected districts for the study were Samastipur (Maize), Meerut (Potato), Lucknow (Mango), Allahabad (Guava), Pratapgarh (Aonla), Sonepat (Mushroom) and Indore (Wheat, Soybean, Tomato). Through stratified random sampling from each selected commodities 15 processors were selected for identifying entrepreneurial environment and 2 experts from each commodities were selected purposively who were engaged in processing for devising strategy to promote value chain development.

\section{Statistical methods}

To identify the entrepreneurial environment the driving forces for processors were 
identified through review of literature and expert opinion. To determine the restraining forces for processors the scale developed by Gills (2015) was used with modification. Thus, for its standardization, reliability and validity was calculated. Thus the reliability coefficient as per Spearman Brown for restraining forces among processors was 0.95 and Cronbach's alpha to be 0.92 . The content validity S-CVI/Ave was worked out to be 0.90 following Lynns' method which indicates the high reliability and validity of scale. Then through interview schedule the data was collected and analysed using Kruskal-Wallis test.It is used for comparing more than two samples that are independent, or not related. The parametric equivalence of the KruskalWallis test is the one-way analysis of variance (ANOVA). The test statistic (for large sample)

is

$$
K=\frac{12}{N(N+1)} \sum_{i=1}^{g} n_{i}\left(\frac{\sum_{j=1}^{n_{i}} r_{i j}}{n_{i}}-\frac{N+1}{2}\right)^{2}
$$

which

follows a $\chi^{2}$ distribution with (g-1) degrees of freedom, where $\mathrm{g}$ is the number of groups $n_{i}$ is the number of observations in $i^{\text {th }}$ group, $r_{i j}$ is the rank (among all observations) of $j^{\text {th }}$ observation from group $i$ and $N$ is the total number of observations across all groups.

The strategies to promote value chain were identified through review of literature and experts' opinion. Then the identified strategies were ranked through interview schedule from 18 experts of organizations using Alfares and Duffuaa (2009) methodology which is based on linear rank-weight linear function whose slope (Sn) depends on the number of criteria (n). This linear relationship specifies the average weight for each rank (r) for an individual judge $(\mathrm{m})$, assuming a weight of $100 \%$ for the first-ranked (most important) dimension. To determine criteria weight even from single judge is difficult as it is difficult to assign relative weights to different decision criteria. Naturally, it becomes more tedious to obtain criteria weights from several decision makers. Quite often, judges are much more comfortable in simply assigning ordinal ranks to the different criteria under consideration. Thus, the beauty of Alfares and Duffuaa method is to convert the criteria rank given by judges into relative criteria weights, in addition, assigning $100 \%$ to rank 1 and subsequently as the rank decreases the percentage will decrease.

In present study to determine aggregate criteria weights of each dimensions or statement, the 18 experts ranked the statements within each dimension as well as each dimension. Thus, after obtaining aggregate weights, one can identify the important aspect of strategy development to promote value chain.

$$
\begin{aligned}
& \mathrm{Sn}=3.19514+\frac{37.75756}{n} \\
& \mathrm{Wrn}=100-\mathrm{Sn}(\mathrm{r}-1)
\end{aligned}
$$

Where,

$\mathrm{n}=$ number of criteria

$\mathrm{r}=$ rank assign to statement or criteria

Wrn $=$ weight assign to criteria based on individual rank

$\mathrm{W}=$ aggregate weight of respondent

\section{Results and Discussion}

The entrepreneurial environment for existing value addition scenario was studied in six dimensions i.e. technical, infrastructure, market, finance, legal and socio-personal.

These six dimensions were broadly studied under driving and restraining forces. The nine different types of processors were ranked based on mean rank obtained through Kruskalwalis in each dimension. 


\section{Technical driving and restraining forces}

For technical driving force, mean rank of soybean processor (119.40) was highest followed by aonla processor (105.7) and maize processor (95.93) probably due to affordability and timely access to suitable variety of raw material, timely labour availability and access to technical information as indicated in Table 2. However, for potato and tomato processor, the suitable variety of raw material was not easily available and they were costly as well. The potato processors at Meerut were mainly purchasing suitable variety of potato from Gujarat due to unsuitability of potato available locally for processing which increases the cost of raw material. Also the tomatoes at Indore district were supplied from Dhar district mainly which increases the price of tomato for processors who were mainly confined at Indore district. For technical restraining forces, guava processors (113) followed by maize (94.66) and mango processors (86.20) had obtained higher mean rank due to lack of training and its follow up support as well as lack of support for enterprise diversification whereas in case of wheat and mushroom processor access to training and machinery was there.

\section{Infrastructure driving and restraining forces}

For infrastructure driving forces, soybean processor (118.33) followed by mushroom (107.50) and aonla (80.20) processors ranked higher due to access to institutional support whereas tomato (41) and potato (29.13) processors ranked lower due to lack of institutional support as evident from Table 3. The majority of soybean processors were getting assistance from Centre of Excellence on Soybean Processing and Utilization, Bhopal, ICAR-Indian Institute of Soybean Research, Indore and Soybean Processing
Association of India (SOPA), Indore. The mushroom processors were getting institutional support from Haryana Agro Industries Corporation Limited (HAIC) and National Institute for Food Technology Entrepreneurship and Management (NIFTEM). For infrastructure restraining forces, aonla processor (110.50) followed by maize (95.36) and guava (94.16) processors were ranked higher due to high initial investment, inadequate storage facility for guava and interrupted power supply for maize processor. However, potato processors (36.63) as well as mango processors (48.06) were ranked lower due to low initial investment for making potato bhujjia and chips from potato and pickles from mango and less problem of storage as they were mainly seasonal processors.

\section{Market driving and restraining forces}

Table 4 represents that in market driving forces, fruit processors (mango, aonla and guava) were ranked higher due to availability of direct marketing facility and direct contact with producers for getting raw material directly from farmers. However, potato (24.20) and tomato (18.13) processors were ranked lower due to low access to online market and market information as well as nonavailability of fresh produce directly from farmers. In case of market restraining forces, soybean (101) and potato (91.40) processors were ranked higher due to high price fluctuation of raw material, difficulty in predicting demand of processed product and involvement of intermediaries in purchasing raw material whereas maize processor (8) got lowest rank due to low fluctuation in demand and price.

\section{Financial driving and restraining forces}

In case of financial driving forces, aonla (102.3) followed by soybean (94.5) and wheat 
(93.23) processors got higher rank due to access to credit facility and information about price policy as evident from Table 5. For financial restraining forces, potato (110.93) and guava (95.70) processors were ranked higher due to difficulty in obtaining subsidy and high rate of interest. However, mushroom and wheat processor got lowest ranked due to supporting price policy.

\section{Legal driving and restraining forces}

In case of legal driving forces, soybean processor (117.23) was ranked highest due to ease in registering enterprise and implementation of GST, following digital payment etc. Although, potato processor (8.6) ranked lowest due to difficulty in registering enterprise and following digital payment as most of the processors were engaged in processing at local level retrieved from Table 6. In case of legal restraining forces, fruit processor ranked highest due to effect of demonetization on production and labour payment, difficulty in getting licence and high GST rate, however, these problems were found to be lower in wheat (31) and maize (32.8) processor, hence they were ranked lowest.

\section{Socio-personal driving and restraining forces}

Aonla (101.43) processors followed by mango processors ranked higher in socio-personal driving forces due to family support in processing, innovativeness in making value added products of aonla and access to courses on food processing especially mango pickles whereas potato (34.03) processor ranked lowest due to lack of access to food processing courses, innovativeness and low risk taker (Table 7).

In case of socio-personal restraining forces, aonla (90.26) and mango (84.53) processors were ranked higher due to lack of entrepreneurial education and poor motivation. Also, in case of aonla differences based on caste and political biasness were seen. However, potato (39.13) processor was ranked lowest due to no differences based on caste, political biasness and negative attitude towards society etc.

\section{Overall driving and restraining forces}

From Table 8 it can be observed that soybean processors (614.71) followed by aonla processors (567) were having highest mean rank for total driving forces which indicates that entrepreneurial environment was more conducive for soybean and aonla processor. The driving force was highest for soybean processor because for technical (119.4), infrastructure (118.33) and legal (117.23) dimension the mean rank for soybean processor was highest compared to other processors. Whereas, for aonla processors the mean rank were higher in financial (102.36) and socio-personal (101.43) driving forces.

However, Potato processor (135.51) and tomato processor (242.42) were ranked lowest for total driving forces clearly indicating that entrepreneurial environment for value chain development was least favourable for them. In every dimension (technical, infrastructure, finance, legal and socio-personal) except market potato processors ranked lowest for driving forces. For market driving force, tomato processor was ranked lowest.

In case of total restraining forces, guava processor (546) followed by mango processor (473.65) were having higher mean rank. The mean rank of guava processor was highest in technical (113.4), financial (100.66) and legal (118.93) dimensions of restraining forces, therefore, the restraining forces was highest for guava processor. 
Table.1 Post-harvest losses and production status of selected commodities under study

\begin{tabular}{|c|c|c|c|c|c|}
\hline & Commodities & $\begin{array}{l}\text { Post- } \\
\text { Harvest } \\
\text { losses }\end{array}$ & Present Status & VCD Potential & Institutional Support \\
\hline \multirow{3}{*}{ 想 } & Mango & 9.16 & $\begin{array}{l}{\text { UP Rank } 1^{\text {st }} \text { in }} \text { Production } \\
\text { (4540230 MT) } \\
\text { Lucknow } \\
\text { (585200 MT) }\end{array}$ & $\begin{array}{l}\text { Bars, Candy, Juice, } \\
\text { Squash, Jam, Jelly, } \\
\text { Slices, Pickles etc. }\end{array}$ & $\begin{array}{l}\text { CISH } \\
\text { KVK }\end{array}$ \\
\hline & Guava & $\begin{array}{c}15.88 \\
\text { (highest) }\end{array}$ & $\begin{array}{l}\text { UP Rank } 1^{\text {st }} \text { in } \\
\text { Production } \\
\text { (919940MT) } \\
\text { Allahabad } \\
\text { (332200 MT) }\end{array}$ & $\begin{array}{l}\text { Candy, Juice, Squash, } \\
\text { etc. }\end{array}$ & KVK \\
\hline & Aonla & - & $\begin{array}{l}\text { UP Rank 1st } \\
\text { Production } \\
\text { (380700MT) } \\
\text { Pratapgarh } \\
\text { (185820 MT) }\end{array}$ & $\begin{array}{l}\text { Candy, Juice, Murabba } \\
\text { etc. }\end{array}$ & KVK \\
\hline \multirow{3}{*}{ 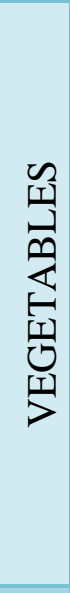 } & Potato & 9 & $\begin{array}{l}\text { UP Rank 1st in } \\
\text { Production } \\
\text { (13916000 MT) }\end{array}$ & $\begin{array}{l}\text { Chips, Finger Chips, } \\
\text { Papad, Aloobhujia }\end{array}$ & $\begin{array}{l}\text { CPRI (RS) } \\
\text { Modipuram, }\end{array}$ \\
\hline & Tomato & $\begin{array}{c}12.98 \\
\text { (highest) }\end{array}$ & $\begin{array}{c}\text { Production in MP } \\
\text { (3102000 MT) } \\
\text { Dhar } \\
\text { (918600MT) }\end{array}$ & $\begin{array}{l}\text { Sauce, Chutney, Puree, } \\
\text { Ketchup, powder, } \\
\text { instant soup }\end{array}$ & KVK \\
\hline & Mushroom & $\begin{array}{l}12.5 \\
\text { (second } \\
\text { highest) }\end{array}$ & $\begin{array}{c}\text { Haryana Shares } \\
\text { (15000MT) } 15.84 \\
\% \text { of button } \\
\text { mushroom } \\
\text { production }\end{array}$ & $\begin{array}{l}\text { Powder, Fresh /Dry } \\
\text { oyster, spawn, soup, } \\
\text { pickles, patties }\end{array}$ & $\begin{array}{c}\text { Mushroom Research } \\
\text { \& Development } \\
\text { Project at Murthal } \\
\text { (Sonepat) }\end{array}$ \\
\hline \multirow{3}{*}{ 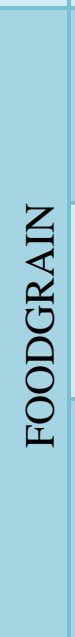 } & Wheat & $4.93 \%$ & $\begin{array}{l}\text { MP major } \\
\text { producer of wheat } \\
2850 \text { MT \& } \\
\text { shares } 19.77 \%\end{array}$ & $\begin{array}{l}\text { Samolina, maida, pasta, } \\
\text { macroni, sewain }\end{array}$ & IARI (RS) \\
\hline & Maize & $4.63 \%$ & $\begin{array}{c}\text { Bihar leading } \\
\text { producer of } \\
\text { Maize (3313 MT) } \\
\text { \& shares } 9.68 \%\end{array}$ & $\begin{array}{l}\text { Corn flakes, sweet corn, } \\
\text { starch, glucose, oil, } \\
\text { glucose syrup, pop corn }\end{array}$ & $\begin{array}{c}\text { RAU, } \\
\text { IARI (RS) }\end{array}$ \\
\hline & Soybean & $2.38 \%$ & $\begin{array}{c}\text { MP Rank 1st } \\
\text { (1139 MT \& } \\
\text { shares 61.26\%) }\end{array}$ & $\begin{array}{l}\text { full-fat soya flour, soya } \\
\text { fortified biscuits, soya } \\
\text { paneer, soya milk, soya } \\
\text { candy, soya nuts, nutri- } \\
\text { nuggets, soya sticks }\end{array}$ & $\begin{array}{c}\text { IISR } \\
\text { CIAE, Bhopal }\end{array}$ \\
\hline
\end{tabular}

(Source: Horticultural Statistics At A Glance, 2017 \& Agricultural Statistics At A Glance, 2016) 
Table.2 Mean Rank of Technical Dimension by different types of processors for driving and restraining forces as per Kruskalwalis

\begin{tabular}{|c|c|c|c|c|c|c|c|c|c|c|}
\hline \multicolumn{5}{|c|}{ Technical Driving Forces } & \multicolumn{6}{|c|}{ Technical Restraining Forces } \\
\hline \multirow{2}{*}{$\begin{array}{l}\text { Processor } \\
\text { Soybean }\end{array}$} & \multirow{2}{*}{$\begin{array}{c}\text { Mean } \\
\text { Rank*** } \\
\mathrm{X}^{2} 110.23 \\
119.40\end{array}$} & \multicolumn{3}{|c|}{ Groups } & \multirow{2}{*}{$\begin{array}{l}\text { Processor } \\
\text { Guava }\end{array}$} & \multirow{2}{*}{$\begin{array}{c}\text { Mean } \\
\text { Rank*** } \\
\mathrm{X}^{2} 70.86 \\
113.40\end{array}$} & \multicolumn{4}{|c|}{ Groups } \\
\hline & & A & & & & & A & & & \\
\hline Aonla & 105.70 & A & $\mathrm{B}$ & & Maize & 94.66 & A & $\mathrm{B}$ & & \\
\hline Maize & 95.93 & A & B & & Mango & 86.20 & A & B & & \\
\hline Mushroom & 79.86 & A & B & & Soybean & 78.50 & A & $\mathrm{B}$ & $\mathrm{C}$ & \\
\hline Guava & 77.93 & A & $\mathrm{B}$ & & Potato & 65.70 & & B & $\mathrm{C}$ & \\
\hline Mango & 63.46 & & B & $\mathrm{C}$ & Tomato & 65.10 & & B & $\mathrm{C}$ & \\
\hline Wheat & 27.56 & & & $\mathrm{C}$ & Aonla & 57.26 & & $\mathrm{~B}$ & $\mathrm{C}$ & $\mathrm{D}$ \\
\hline Tomato & 22.73 & & & $\mathrm{C}$ & Mushroom & 34.33 & & & $\mathrm{C}$ & $\mathrm{D}$ \\
\hline Potato & 19.40 & & & $\mathrm{C}$ & Wheat & 16.83 & & & & D \\
\hline
\end{tabular}

Table.3 Mean Rank of Infrastructure Dimension by different types of processors for driving and restraining forces as per Kruskalwalis

\begin{tabular}{|c|c|c|c|c|c|c|c|c|c|c|}
\hline \multicolumn{6}{|c|}{ Infrastructure Driving Forces } & \multicolumn{5}{|c|}{ Infrastructure Restraining Forces } \\
\hline \multirow{2}{*}{\begin{tabular}{|l} 
Processor \\
Soybean
\end{tabular}} & \multirow{2}{*}{$\begin{array}{c}\text { Mean } \\
\text { Rank*** } \\
\mathbf{X}^{2} \mathbf{6 9 . 3 8} \\
118.33\end{array}$} & \multicolumn{4}{|c|}{ Groups } & \multirow{2}{*}{$\begin{array}{c}\text { Processor } \\
\text { Aonla }\end{array}$} & \multirow{2}{*}{$\begin{array}{c}\text { Mean } \\
\text { Rank**** } \\
\mathbf{X}^{\mathbf{2}} \mathbf{5 1 . 4 7} \\
110.50\end{array}$} & \multicolumn{3}{|c|}{ Groups } \\
\hline & & $\mathrm{A}$ & & & & & & A & & \\
\hline Mushroom & 107.50 & A & B & & & Maize & 95.36 & A & B & \\
\hline Aonla & 80.20 & A & B & C & & Guava & 94.16 & A & B & \\
\hline Mango & 67.20 & & B & $\mathrm{C}$ & D & Mushroom & 58.86 & & B & $\mathrm{C}$ \\
\hline Wheat & 63.40 & & $\mathrm{~B}$ & & D & Soybean & 56.46 & & B & $\mathrm{C}$ \\
\hline Guava & 53.23 & & & & D & Tomato & 55.96 & & B & $\mathrm{C}$ \\
\hline Maize & 51.93 & & & & D & Wheat & 55.96 & & B & $\mathrm{C}$ \\
\hline Tomato & 41.06 & & & & D & Mango & 48.06 & & & $\mathrm{C}$ \\
\hline Potato & 29.13 & & & & $\mathrm{D}$ & Potato & 36.63 & & & $\mathrm{C}$ \\
\hline
\end{tabular}

***significant at $<0.001$ per cent level; Mean ranks having same letters are not significantly different 
Table.4 Mean rank of Market Dimension by different types of processors for driving and restraining forces as per Kruskalwalis

\begin{tabular}{|c|c|c|c|c|c|c|c|c|c|}
\hline \multicolumn{5}{|c|}{ Market Driving Forces } & \multicolumn{5}{|c|}{ Market Restraining Forces } \\
\hline \multirow{2}{*}{$\begin{array}{c}\text { Processor } \\
\text { Mango }\end{array}$} & \multirow{2}{*}{$\begin{array}{c}\text { Mean Rank }{ }^{* * * *} \\
X^{2} 76.90 \\
94.43\end{array}$} & \multicolumn{3}{|c|}{ Groups } & \multirow{2}{*}{$\begin{array}{l}\text { Processor } \\
\text { Soybean }\end{array}$} & \multirow{2}{*}{$\begin{array}{c}\text { Mean Rank*** } \\
X^{2} 59.87 \\
101.13\end{array}$} & \multicolumn{3}{|c|}{ Groups } \\
\hline & & $\mathrm{A}$ & & & & & A & & \\
\hline Aonla & 92.46 & A & & & Potato & 91.26 & A & B & \\
\hline Guava & 91.13 & A & & & Tomato & 88.06 & A & B & \\
\hline Soybean & 86.83 & A & & & Aonla & 73.46 & A & B & \\
\hline Wheat & 85.20 & A & B & & Guava & 71.46 & A & B & \\
\hline $\begin{array}{c}\text { Mushroo } \\
\text { m }\end{array}$ & 78.73 & A & B & & Mushroom & 69.13 & A & B & \\
\hline Maize & 40.86 & & B & $\mathrm{C}$ & Mango & 56.30 & A & B & \\
\hline Potato & 24.20 & & & $\mathrm{C}$ & Wheat & 53.16 & & B & $\mathrm{C}$ \\
\hline Tomato & 18.13 & & & $\mathrm{C}$ & Maize & 8.00 & & & $\mathrm{C}$ \\
\hline
\end{tabular}

***significant at $<0.001$ per cent level; Mean ranks having same letters are not significantly different

Table.5 Mean Rank of Finance Dimension by different types of processors for driving and restraining forces as per Kruskalwalis

\begin{tabular}{|c|c|c|c|c|c|c|c|c|c|}
\hline \multicolumn{3}{|c|}{ Financial Driving Forces } & \multicolumn{3}{c|}{ Financial Restraining Forces } \\
\hline Processor & $\begin{array}{c}\text { Mean } \\
\text { Rank*** } \\
\mathrm{X}^{2} 63.83\end{array}$ & \multicolumn{2}{|c|}{ Groups } & Processor & $\begin{array}{c}\text { Mean } \\
\text { Rank*** } \\
\mathrm{X}^{2} 49.179\end{array}$ & \multicolumn{2}{|c|}{ Groups } \\
\hline Aonla & 102.36 & A & & & Potato & 110.93 & A & & \\
\hline Soybean & 94.50 & A & B & & Guava & 95.70 & A & B & \\
\hline Wheat & 93.23 & A & B & & Mango & 87.46 & A & B & C \\
\hline Guava & 88.33 & A & B & & Aonla & 73.93 & A & B & C \\
\hline Maize & 65.63 & A & B & C & Maize & 53.43 & & B & C \\
\hline Tomato & 56.56 & & B & C & Tomato & 50.23 & & & C \\
\hline $\begin{array}{c}\text { Mushroo } \\
\text { m }\end{array}$ & 55.43 & & B & C & Soybean & 49.16 & & & C \\
\hline Potato & 28.43 & & & C & Wheat & 47.86 & & & C \\
\hline Mango & 27.50 & & & C & Mushroom & 43.26 & & & C \\
\hline
\end{tabular}

***significant at $<0.001$ per cent level; Mean ranks having same letters are not significantly different 
Table.6 Mean Rank of Legal Dimension by different types of processors for driving and restraining forces as per Kruskalwalis

\begin{tabular}{|c|c|c|c|c|c|c|c|c|c|}
\hline \multicolumn{5}{|c|}{ Legal Driving Forces } & \multicolumn{5}{|c|}{ Legal Restraining Forces } \\
\hline \multirow{2}{*}{$\begin{array}{l}\text { Processor } \\
\text { Soybean }\end{array}$} & \multirow{2}{*}{$\begin{array}{c}\text { Mean } \\
\text { Rank*** } \\
\mathbf{X}^{\mathbf{2}} \mathbf{7 6 . 6 2} \\
117.23\end{array}$} & \multicolumn{3}{|c|}{ Groups } & \multirow{2}{*}{$\begin{array}{c}\text { Processor } \\
\text { Guava }\end{array}$} & \multirow{2}{*}{$\begin{array}{c}\text { Mean Rank**** } \\
\mathbf{X}^{\mathbf{2}} \mathbf{9 3 . 9 4} \\
118.93\end{array}$} & \multicolumn{3}{|c|}{ Groups } \\
\hline & & A & & & & & A & & \\
\hline Aonla & 90.96 & A & B & & Mango & 118.30 & A & & \\
\hline $\begin{array}{c}\text { Mushroo } \\
\text { m }\end{array}$ & 83.96 & A & B & & Aonla & 86.10 & A & B & \\
\hline Guava & 78.83 & A & B & & Potato & 79.90 & A & B & \\
\hline Wheat & 70.86 & & B & & Tomato & 55.46 & & B & $\mathrm{C}$ \\
\hline Tomato & 67.10 & & B & & $\begin{array}{c}\text { Mushro } \\
\text { om }\end{array}$ & 45.36 & & B & $\mathrm{C}$ \\
\hline Maize & 47.76 & & B & $\mathrm{C}$ & Soybean & 43.93 & & B & $\mathrm{C}$ \\
\hline Maize & 46.66 & & B & $\mathrm{C}$ & Maize & 32.80 & & & $\mathrm{C}$ \\
\hline Potato & 8.60 & & & $\mathrm{C}$ & Wheat & 31.20 & & & $\mathrm{C}$ \\
\hline
\end{tabular}

$* * *$ significant at $<0.001$ per cent level; Mean ranks having same letters are not significantly different

Table.7 Mean Rank of Socio-personal Dimension by different types of processors for driving and restraining forces as per Kruskalwalis

\begin{tabular}{|c|c|c|c|c|c|c|c|c|}
\hline \multicolumn{3}{|c|}{ Social Personal Driving Forces } & \multicolumn{3}{c|}{ Social Personal Restraining Forces } \\
\hline Processor & $\begin{array}{c}\text { Mean Rank*** } \\
\mathrm{X}^{2} 46.45\end{array}$ & \multicolumn{2}{|c|}{ Groups } & Processor & $\begin{array}{c}\text { Mean Rank*** } \\
\text { X }^{2} 33.76\end{array}$ & Groups \\
\hline Aonla & 101.43 & A & & Aonla & 90.26 & A & \\
\hline Mango & 94.93 & A & & Mango & 84.53 & A B \\
\hline Soybean & 90.20 & A & B & Maize & 82.40 & A B C \\
\hline Wheat & 74.83 & A & B C & Tomato & 81.83 & A B C \\
\hline Guava & 64.50 & A & B & C & Guava & 81.80 & A B C \\
\hline Maize & 62.66 & A & B C & Wheat & 62.70 & A B C \\
\hline Mushroom & 45.70 & & B & C & Soybean & 48.23 & A B & C \\
\hline Tomato & 43.70 & & C & Mushroom & 41.10 & B C \\
\hline Potato & 34.03 & & & C & Potato & 39.13 & & C \\
\hline
\end{tabular}

***significant at $<0.001$ per cent level; Mean ranks having same letters are not significantly different 
Table.8 Overall driving and restraining forces among different types of processor as per Kruskalwalis

\begin{tabular}{|c|c|c|c|c|c|c|c|c|}
\hline \multicolumn{5}{|c|}{ Total Driving Forces } & \multicolumn{4}{|c|}{ Total Restraining Forces } \\
\hline Processor & & \multicolumn{3}{|c|}{ Groups } & Processor & & \multicolumn{2}{|c|}{ Groups } \\
\hline & & & & & & & & \\
\hline Soybean & 614.71 & A & & & Guava & 546.35 & A & \\
\hline Aonla & 567.00 & A B & & & Mango & 473.65 & A B & \\
\hline $\begin{array}{c}\text { Mushroo } \\
\text { m }\end{array}$ & 463.67 & B & $\mathrm{C}$ & & Aonla & 463.66 & A B & \\
\hline Guava & 457.08 & B & $\mathrm{C}$ & & Potato & 444.33 & B & $\mathrm{C}$ \\
\hline Mango & 408.18 & & $\mathrm{C}$ & & Tomato & 398.36 & B & $\mathrm{C}$ \\
\hline Wheat & 388.72 & & $\mathrm{C}$ & & Soybean & 382.72 & B & $\mathrm{C}$ \\
\hline Maize & 372.18 & & C & & Maize & 338.92 & & $\mathrm{C}$ \\
\hline Tomato & 242.42 & & & D & $\begin{array}{c}\text { Mushroo } \\
\mathrm{m}\end{array}$ & 331.10 & & $\mathrm{C}$ \\
\hline Potato & 135.51 & & & $\mathrm{D}$ & Wheat & 270.37 & & $\mathrm{C}$ \\
\hline
\end{tabular}

***significant at $<0.001$ per cent level; Mean ranks having same letters are not significantly different

Table.9 Profitability comparison between processors and producer for all commodities

\begin{tabular}{|c|c|c|c|c|c|c|}
\hline & $\begin{array}{l}\text { Commo- } \\
\text { dities }\end{array}$ & $\begin{array}{l}\text { Particular } \\
\text { (Rs/Q) }\end{array}$ & $\begin{array}{l}\text { Processing unit } \\
\qquad(\mathrm{n}=15)\end{array}$ & $\begin{array}{l}\text { Production unit } \\
\qquad(\mathrm{n}=20)\end{array}$ & Difference & Times \\
\hline \multirow{6}{*}{$\begin{array}{l}\underline{\underline{D}} \\
\stackrel{\alpha}{\underline{I}}\end{array}$} & \multirow[t]{2}{*}{ Aonla } & Cost & 7864.715 & 252.9481 & 7611.77 & 31.09 \\
\hline & & Net return & 6801.92 & 949.57 & 5852.38 & 7.16 \\
\hline & \multirow[t]{2}{*}{ Guava } & Cost & 10467.11 & 402.10 & 7611.76 & 26.03 \\
\hline & & Net return & 5732.88 & 2317.22 & 3415.65 & 2.47 \\
\hline & \multirow[t]{2}{*}{ Mango } & Cost & 6308.99 & 1420.40 & 4888.58 & 4.44 \\
\hline & & Net return & 6557.67 & 1379.59 & 518.08 & 4.75 \\
\hline \multirow{6}{*}{ 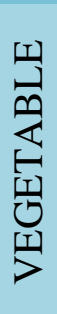 } & \multirow[t]{2}{*}{ Potato } & Cost & 6334.12 & 481.99 & 5852.13 & 13.14 \\
\hline & & Net return & 5710.30 & -166.04 & 5876.34 & 34.39 \\
\hline & \multirow[t]{2}{*}{ Tomato } & Cost & 6165.97 & 262.03 & 5903.94 & 23.53 \\
\hline & & Net return & 4422.91 & 537.96 & 3884.95 & 8.22 \\
\hline & \multirow{2}{*}{$\begin{array}{c}\text { Mushroo } \\
\text { m }\end{array}$} & Cost & 7201.53 & 5074.78 & 2126.74 & 1.41 \\
\hline & & Net return & 2098.72 & 1425.21 & 673.51 & 1.47 \\
\hline \multirow{6}{*}{ 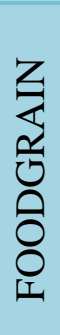 } & \multirow[t]{2}{*}{ Wheat } & Cost & 5130.34 & 1061.35 & 4068.99 & 4.83 \\
\hline & & Net return & 3850.77 & 848.22 & 3002.55 & 4.53 \\
\hline & \multirow[t]{2}{*}{ Maize } & Cost & 9617.41 & 1196.99 & 8420.42 & 8.03 \\
\hline & & Net return & 13991.66 & 239.04 & 13752.55 & 58.53 \\
\hline & \multirow[t]{2}{*}{ Soybean } & Cost & 3313.98 & 2447.53 & 866.44 & 1.35 \\
\hline & & Net return & 2236.39 & 766.39 & 1470.00 & 2.91 \\
\hline
\end{tabular}


Table.10 Devising strategy through Alfares method to promote value chain

\begin{tabular}{|c|c|c|c|}
\hline $\begin{array}{l}\text { S. } \\
\text { No. }\end{array}$ & Strategies & $\begin{array}{c}\text { Average } \\
\text { weight }\end{array}$ & Rank \\
\hline 1 & Post-harvest management Dimension & & \\
\hline i. & $\begin{array}{l}\text { Sensitizing the producer about post-harvest losses at } \\
\text { individual as well as aggregate level }\end{array}$ & 75.45 & III \\
\hline ii. & $\begin{array}{l}\text { Provide access to different post-harvest management } \\
\text { techniques }\end{array}$ & 94.73 & I \\
\hline iii. & $\begin{array}{l}\text { Provide information about several value addition } \\
\text { process/ techniques }\end{array}$ & 82.46 & II \\
\hline 2 & Market Dimension & & \\
\hline i. & Timely and regular access to market intelligence & 81.58 & III \\
\hline ii. & $\begin{array}{l}\text { Promote direct marketing facility at reasonable price } \\
\text { (contract farming between producers \& processors) }\end{array}$ & 87.72 & I \\
\hline iii. & Provide online marketing support & 83.34 & II \\
\hline 3. & Infrastructure Dimension & & \\
\hline i. & Provision of cold storage adequately and reasonably & 85.97 & II \\
\hline ii. & Facilitate collective processing and collective marketing & 92.98 & I \\
\hline iii. & Access to required machinery for value addition & 73.69 & III \\
\hline 4. & Institutional Dimension & & \\
\hline i. & $\begin{array}{l}\text { Provide training to promote value addition through KVK } \\
\text { etc. }\end{array}$ & 89.47 & II \\
\hline ii. & Encourage district level processing centre & 92.98 & I \\
\hline iii. & Motivation and follow up support to producers & 71.94 & III \\
\hline 5. & Information Dimension & & \\
\hline i. & $\begin{array}{l}\text { Functional Single window delivery system along with } \\
\text { toll free number for providing information to start up } \\
\text { agripreneur }\end{array}$ & 96.49 & $\mathrm{I}$ \\
\hline ii. & $\begin{array}{l}\text { Awareness among producers related to various schemes } \\
\text { started by government for promoting entrepreneurship } \\
\text { and value addition }\end{array}$ & 87.72 & II \\
\hline iii. & $\begin{array}{l}\text { Access to different credit facility availability to } \\
\text { producers }\end{array}$ & 68.43 & III \\
\hline
\end{tabular}


Table.11 Important dimension for strategy making as per Alfares method

\begin{tabular}{|l|l|l|l|l|l|l|}
\hline Rank & PHM & Market & Infrastructure & Institutional & Information & Wrn \\
\hline $\mathbf{1}$ & 0 & 3 & 0 & 3 & 12 & 100 \\
\hline $\mathbf{2}$ & 0 & 5 & 0 & 10 & 3 & 89.25 \\
\hline $\mathbf{3}$ & 2 & 7 & 3 & 3 & 3 & 78.50 \\
\hline $\mathbf{4}$ & 2 & 3 & 11 & 2 & 0 & 67.76 \\
\hline $\mathbf{5}$ & 14 & 0 & 4 & 0 & 0 & 57.01 \\
\hline $\mathbf{f}$ & 18 & 18 & 18 & 18 & 18 & \\
\hline $\begin{array}{l}\text { Aggregate } \\
\text { Weight }\end{array}$ & 1090.721 & 1499.094 & 1208.934 & 1563.574 & 1703.28 & \\
\hline $\begin{array}{l}\text { Average } \\
\text { W }\end{array}$ & 60.59 & 83.28 & 67.16 & 86.86 & 94.62 & \\
\hline Rank & $\mathbf{V}$ & III & IV & II & I & \\
\hline PHM Por & & & & & \\
\hline
\end{tabular}

PHM= Post harvest management,

Wrn $=$ Weight as per rank

$\mathrm{W}=$ Average weight

However, the restraining forces were observed to be less in case of Wheat (270) and Mushroom (331) processor, hence, they were ranked lowest for restraining forces. In case of wheat processor, technical (16.83) and legal (31.20) dimensions obtained lowest score whereas in case of mushroom processor, financial (46.96) and socio-personal (41.10) dimensions obtained lowest score for restraining forces.

\section{Devising strategies to promote value chain among producers}

Since through processing or value addition of fresh produce the net return is more compared to produce as indicated in Table 9. The profitability (net return) of processing unit was more as compared to production unit in all selected commodities under study i.e. aonla (7.16 times), guava (2.47 times), mango (4.75 times), potato (34.39 times), tomato (8.22 times), mushroom (1.47 times), wheat (4.53 times), maize (58.53 times) and soybean (2.91 times). Moreover, the processing enhances the shelf life of produce and nutritional quality as well as reduces postharvest losses.

Hence, keeping the importance of value addition and processing in increasing income and reducing post-harvest losses there is need to involve more number of producers into processing in order to increase their income and meet the challenge of doubling farmers' income. Hence, the strategy was developed to promote value chain among farmers through Alfares method, assuming 100 per cent to rank 1 the average weight has been worked out for each statement (criteria) within dimension represented in Table 10.

Thus, within the post-harvest management dimension, the most important aspect of strategy development was found to provide access to post harvest management techniques (94.73), followed by information about value addition or processing techniques (82.46) and sensitizing the producer about post-harvest losses at individual as well as aggregate level 
(75.45). In market dimension, decision makers were of the opinion to stress on contract farming (87.72) to have direct linkage between producers and processors, followed by support for online marketing (83.34) and timely access to market intelligence (81.85). For infrastructure dimension, collective processing and collective marketing was emphasized much (92.96) followed by provision of cold storage (85.97) and access to machinery for value addition (73.69). Within institutional dimension, district level processing unit was found to be important for strategy making (92.94), followed by providing training (89.47) and motivational support (71.94). Within information dimension, single window delivery system with toll free number (96.49) was found to be most important followed by creating awareness about various government schemes (87.72) and access to credit facility (68.43).

\section{Important dimension for devising strategy to promote value addition}

Following Alfares method, the aggregate weight (W) has been calculated for each dimension (criteria) assuming $100 \%$ for rank 1 clear from Table 11. Information dimension (94.62) was found to be most important dimension for devising strategy followed by institutional dimension (86.86), market dimension (83.28), infrastructure dimension (67.16) and post-harvest management dimension (60.59). Thus, it can be inferred that the first step towards promoting value addition among famers to make them aware through providing necessary information related to various schemes after that facilitating relevant institutional and infrastructure support then finally linking them to market.

In conclusion, the study considered the technical, infrastructure, market, financial, legal and socio-personal as determinant of entrepreneurial environment for both driving and restraining forces. The driving forces was most favourable for soybean processor as technical, infrastructure and legal dimensions were favourable for soybean processor at Indore as compared to other processors. After soybean processor, the environment was favourable for aonla processor due to encouraging finance and socio-personal dimensions. Whereas for potato processor the driving forces was least in almost all the dimensions except market as most of the potato processor were local, unregistered and lack achievement motivation. The restraining forces were more for guava processor due to more technical, financial and legal hurdles. As processing increases the value of fresh produce in terms of money as well as quality. So strategy was devise to promote more value addition of produce among producer and it was found that through emphasizing on effective and pertinent information transfer with strong institutional support the objective can be achieved.

\section{References}

Ahwireng-Obeng, F., andPiaray, D. 1999.Institutional obstacles to South African entrepreneurship. South African Journal of Business Management. 30 (3): 78-98.

Alfares H.K., and Duffuaa, S.O. 2009. Assigning cardinal weights in multicriteria decision making based on ordinal ranking. Journal of Multicriteria Decision Analysis. 15(1), 125133.

Beck, T., and Demirguc-Kunt, A. 2006. Small and Medium Size Enterprise: Access to finance as a growth constraint. Journal of Banking and Finance. 30 (1): 29312943.

Black, E.L., F. G. Burton, D.A. Wood and Zimbelman, A.F. 2010. Entrepreneurial 
success: differing perceptions of entrepreneurs and venture capitalists. International Journal of Entrepreneurship and Innovation. 11 (3):189-198.

Bonet, F.P., C. R. Armengot and Martin, M.A.G. 2011.Entrepreneurial Success and Human Resources. International Journal of Manpower.32 (1): 68-80.

Brockner, J., E.T. Higgins and Low, M.B. 2004.Regulatory focus theory and the entrepreneurial process. Journal of Business Venturing. 19(2): 203-220.

Brush, C.G. 2008. Pioneering strategies for entrepreneurial success. Business Horizons.51(1): 21-27.

Caliendo, M. and Kritikos, A.S. 2008.Is entrepreneurial success predictable? An ex-ante analysis of the character-based approach, Kyklos. 61(2):189-214.

Dahlqvist, J., P. Davidsson and Wiklund, J. 2000. Initial conditions as predictors of new venture performance: A replication and extension of the Cooper et al., study. Enterprise and innovation management studies. 1 (1): 1-17.

Delmar, F., P. Davidsson and Gartner, W.B. 2003.Arriving at the high-growth firm.Journal of Business Venturing. 18(2):189-216.

Directorate of Economics and Statistics. 2017. Agricultural Statistics At A Glance 2016. Directorate of Economics and Statistics, Department of Agricultural Cooperation and Farmers Welfare, Ministry of Agriculture and Farmers welfare, Government of India.

Gills, R., 2015.Post-Harvest Decision Making Pattern and Marketing Behaviour of Peri Urban Farmers. PhD thesis, ICARIARI, New Delhi.

Guzman, J., and Santos, F. 2001. The booster function and the entrepreneurial quality: An application to the Province of Seville. Entrepreneurial and Regional Development. 13 (3): 211-228.
Hannan, M., and Freeman, J. 1977.The population ecology of organizations. American Journal of Sociology. 82 (5): 929-964.

Horticulture Statistics Division 2017. Horticultural Statistics At A Glance 2017. Horticulture Statistics Division, Department of Agricultural Cooperation and Farmers Welfare, Ministry of Agriculture and Farmers welfare, Government of India.

Kumar, M., 2007.Explaining entrepreneurial success: a conceptual model. Academy of Entrepreneurship Journal. 13(1): 5777.

Lynn, M. R., 1986. Determination and quantification of content validity. Nursing Research, 35, 382- 385.

Markman, G., and Baron, R. 2003. Personentrepreneurship fit: Why some people are more successful as entrepreneurs than others. Human Resource Management Review. 13 (2): 281-301.

McClelland, D.C. 1961. The Achieving Society, D. Van Nostrand Company Inc., The Free Press, New York, NY.

McCline, R., S. Bhat and Baj, P. 2000. Opportunity recognition: An exploratory investigation of a component of the entrepreneurial process in the context of the health care industry. Entrepreneurship Theory and Practice. 25 (2): 81-94.

Nel, P., D. Prebble and Erasmus, H. 2008. Contemporary tertiary entrepreneurship education in New Zealand: an empirical study of usefulness, paper presented at the 5th Australian Graduate School of Entrepreneurship - International Entrepreneurship Research Exchange, Melbourne, February 5-8.

Penrose, E., 1959. The theory of the growth of the firm. New York: Oxford University Press.

Rauch, A. and Frese, M. 2000. Psychological approaches to entrepreneurial success: a 
general model and an overview of findings. In Cooper, C.L. and Robertson, I.T. (Ed), International Review of Industrial and Organizational Psychology. Vol. 15, John Wiley and Sons Ltd, Chichester., pp. 101-141.

Spearman, C., 1910.Correlation calculated from faulty data. British Journal of Psychology. 3, 271-295.

Thompson, J. L. 2001. Strategic Management (4th ed.). London: Thomson Learning.
Walske, J.M., A. Zacharakis and SmithDoerr, L. 2007.Effects of venture capital syndication networks on entrepreneurial success", paper presented at the Babson College Entrepreneurship Research Conference (BCERC), Madrid, June, available at: http://papers.ssrn.com/sol3/papers.cfm? abstract_id $1 / 41060081$ (accessed July 28 , 2013).

\section{How to cite this article:}

Shruti, M. Singh and Sharma, J.P. 2018. Exploring the Entrepreneurial Environment for Agricultural Processors and developing Strategy to promote Value Addition via Alfares' Method. Int.J.Curr.Microbiol.App.Sci. 7(12): 1994-2009.

doi: https://doi.org/10.20546/ijcmas.2018.712.230 